\title{
Digital maritime container terminal - an element of digitalization of container transportation sys- tems
}

\author{
Elena Koroleva $^{1, *}$, Sergey Sokolov ${ }^{1}$, Irina Makashina ${ }^{2}$, and Evgeniya Filatova $^{2}$ \\ ${ }^{1}$ Admiral Makarov State University of Maritime and Inland Shipping, St. Petersburg, Russia \\ ${ }^{2}$ Admiral Ushakov Maritime State University, Novorossiysk, Russia
}

\begin{abstract}
Sea container terminals are an important infrastructure element in the global supply chain. An increase in the number and size of container ships, as well as an increase in container traffic, led to the expansion of sea container terminals and an increase in their capacity. Extra-large container vessels require more handling equipment, as well as more storage space for containers, and increased throughput capacity for supporting infrastructures. To solve these complex problems in a global competition, the search for integrated effective solutions is required. The article proposes a solution to the integrated digitalization of the sea container terminal.
\end{abstract}

\section{Introduction}

Sea container terminals are an important infrastructure element in the global supply chain. An increase in the number and size of container ships, as well as an increase in container traffic, led to the expansion of sea container terminals and an increase in their capacity. Extra-large container vessels require more handling equipment, as well as more storage space for containers, and increased handling capacity for supporting infrastructures. To solve these complex problems in a global competition, the search for integrated effective solutions is required. One of such solutions may be the project of integrated digitalization of sea container terminals (Fig. 1), based on the use of: a high-bay container storage system; combined marine wireless charging system and automatic ship mooring; drones; automatic cranes; automatic car gates; unmanned trans port.

\footnotetext{
* Corresponding author: korolevaea@gumrf.ru
} 


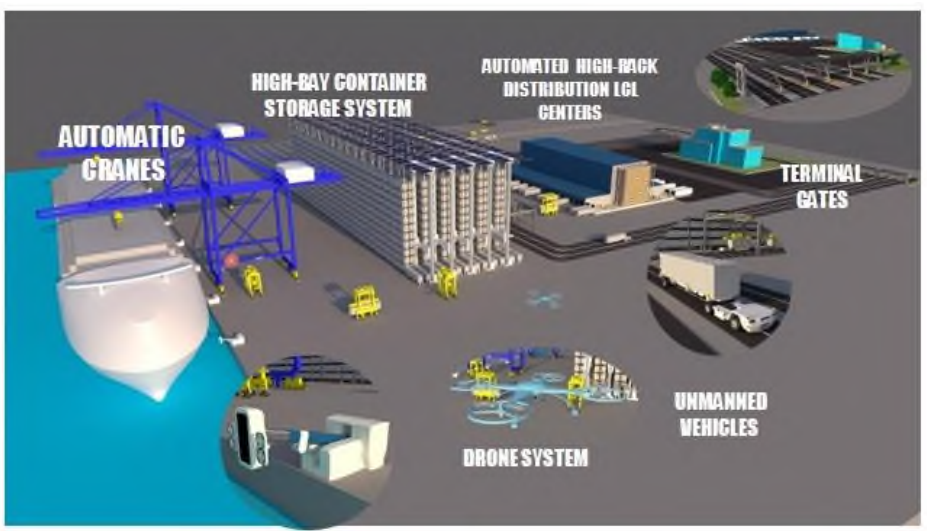

Fig. 1. Integrated Digitalization Project for the Maritime Container Terminal.

\section{High bay storage system for containers}

An example of using a high-rack container storage system is the High Bay Storage System, developed by the German company AMOVA, which is part of the SMS Group. Initially, the system was designed to store metal coils, and later it was proposed for the port industry. The project is currently underway in the port of Jebel Ali, Dubai, United Arab Emirates. High Bay Storage System is an automated solution for storing ISO containers in container ports. The system consists of an automatic high-rack warehouse with 11 storage levels and direct connection with coastal and land loading platforms, providing maximum space utilization - up to 3000 standard containers per hectare with all the advantages of fully automated work (energy saving and labor protection). Elements of the system are presented in table 1.

The high-rack system is modular and can be adapted to the needs of the terminal, both for "brownfield" and for "greenfield" sites. In addition, the system provides unsurpassed stability thanks to purely electrical equipment, energy recovery and minimal environmental impact.

Table 1. System elements High Bay Storage System.

\begin{tabular}{|c|c|c|}
\hline Element & Fig. & Specifications \\
\hline 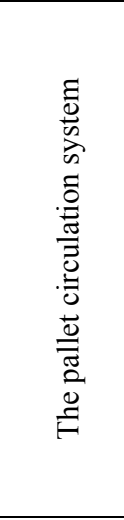 & & $\begin{array}{l}\bullet \text { under the floor, the transport system } \\
\text { connects the high-rack system to the ground } \\
\text { interface of the vehicles; } \\
\text { - the pallet system operates inde- } \\
\text { pendently of the movement of the stacker } \\
\text { cranes without affecting their performance; } \\
-\quad \text { pallets serve as an additional buffer } \\
\text { to separate loading and unloading operations } \\
\text { from land and sea; } \\
-\quad \text { the main components are self- } \\
\text { moving pallets (SDP) on rail tracks and pallet } \\
\text { trucks (PSC); } \\
\text { c the throughput and buffer capacity } \\
\text { can be controlled by the number of pallets. }\end{array}$ \\
\hline
\end{tabular}




\begin{tabular}{|c|c|c|}
\hline Element & Fig. & Specifications \\
\hline 离 & & $\begin{array}{l}\text { standard columns are the main ele- } \\
\text { ments of the rack structure; } \\
\text { for weight; } \\
\text { bay; the design of the racks is optimized } \\
\text { is } 11 \text { tiers; } \\
\text { a the container is stored in separate } \\
\text { a wide variety of } 20 \text {-, } 40 \text {-and } 45 \text {-foot ISO } \\
\text { containers where loads are only rated up to } 36 \\
\text { tons per container. }\end{array}$ \\
\hline 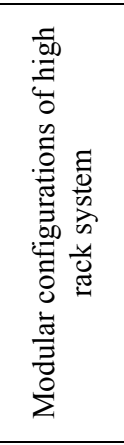 & & $\begin{array}{l}\text { • The basic HBS element is called } \\
\text { "aisle" and consists of } 2 \text { racks, where in be- } \\
\text { tween a rail system for the stacker cranes is } \\
\text { arranged. HBS building consists of multiple } \\
\text { aisles } \\
\text { • Capacity and throughput are } \\
\text { scalable by aisle length, number of aisles and } \\
\text { number of stacker cranes per aisle. With a } \\
\text { multiple aisle high density arrangement the } \\
\text { extension of yard capacity is unmatched in the } \\
\text { port industry with over } 160,000 \text { TEU per } \\
\text { hectare per annum }\end{array}$ \\
\hline 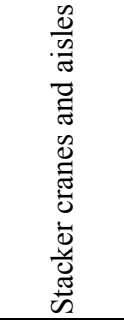 & & $\begin{array}{l}-\quad \text { All container storage or retrieval } \\
\text { movements are performed by stacker cranes } \\
\text { (STCs) } \\
\text { - Container handling is similar to } \\
\text { current practice in terminal industry } \\
\text { - Throughput is scalable by number of } \\
\text { aisles and stacker cranes per aisle }\end{array}$ \\
\hline 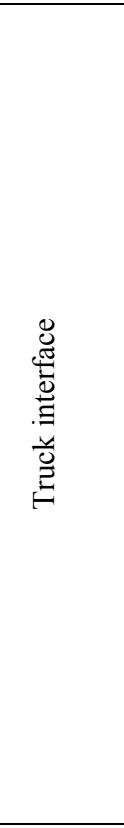 & & 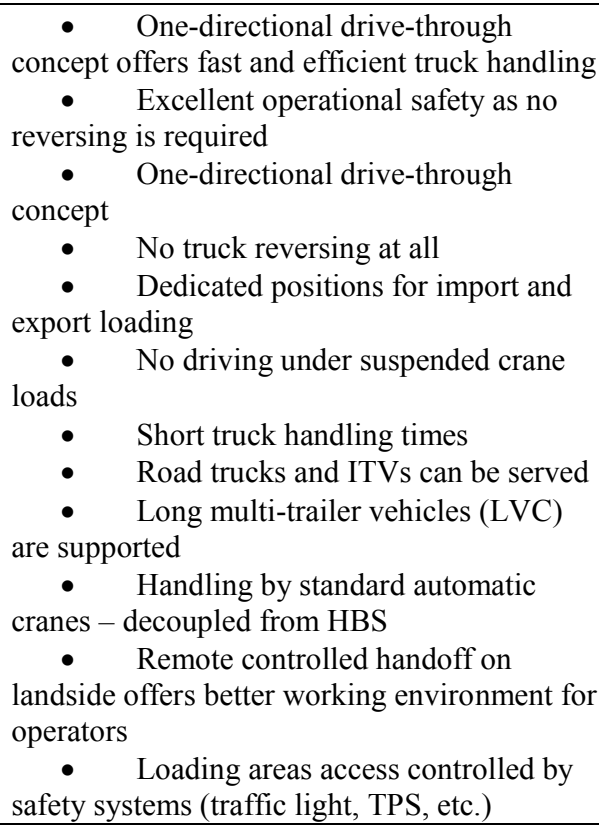 \\
\hline
\end{tabular}




\begin{tabular}{|c|c|c|}
\hline Element & Fig. & $\begin{array}{c}\text { Specifications } \\
\end{array}$ \\
\hline 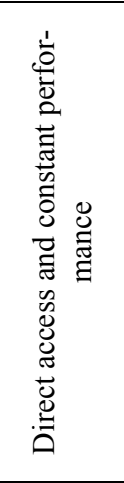 & & $\begin{array}{l}\text { - The use of individual compartments } \\
\text { offers direct access to any container at any } \\
\text { time } \\
\text { - No-reshuffling required } \\
\text { utilization } \\
\text { High performance independent from } \\
\text { efficiency when it is utilized with more than } \\
98 \% \text { (typical operational utilization level for } \\
\text { RTG or straddle carrier yards is significantly } \\
\text { lower) } \\
\text { performance is easy to plan and } \\
\text { predictable and constant }\end{array}$ \\
\hline 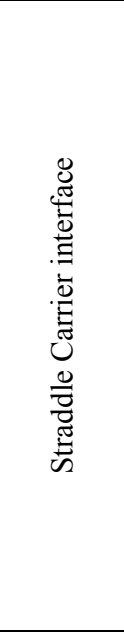 & & $\begin{array}{l}\text { A pair of stationary racks at both } \\
\text { ends of each HBS aisle provide an efficient } \\
\text { interface to water side horizontal transport } \\
\text { - The racks are directly severed by } \\
\text { shuttle carriers and stacker cranes } \\
-\quad \text { Two racks at each aisle end } \\
-\quad \text { Rack capacity } 2 \text { TEU / } 50 \text { tons or } 65 \\
\text { tons } \\
\text { - Stacker cranes can perform } \\
\text { combined input / output moves by utilizing } \\
\text { both racks } \\
\text { - Combined cycles improve } \\
\text { operational efficiency and throughput } \\
\text { - Manual and automated carriers } \\
\text { supported } \\
\text { - Various types of shuttle carriers and } \\
\text { straddle carriers are supported }\end{array}$ \\
\hline
\end{tabular}

Combined marine automatic wireless charging and ship mooring system on the example of a system developed by Cavotec and Wartsila [6, 7]. It is an automatic vacuum technology for mooring a vessel and inductive transmission of electricity. The advantages of the system are:

- fully automated system;

- $\quad$ ensuring fast and safe mooring;

- eliminating the need for conventional mooring cables and cable connections between the ship and shore installations;

- transmission of more than $1 \mathrm{MW}$ of electricity;

- reducing the movement of the vessel at the berth during the rolling operation, ensuring the efficiency of the crane equipment;

- increase the time frame of charging due to the possibility of early connection and late disconnection of charging;

- implementation of more efficient and safe mooring and charging procedures, as well as a significant reduction in harmful gas emissions;

- reduction of physical wear of connecting lines and maintenance costs;

- the exclusion of damage to electrical outlets from sea water, snow and ice; reducing the mobility of the vessel at the berth, providing faster and more efficient handling;

- the ability to connect to AC and DC networks, both alternately and simultaneously. 


\section{Unmanned aerial vehicles (drone system)}

The use of unmanned aerial vehicles is necessary in order to ensure safety and increase the operational efficiency of sea container terminals, allowing:

- optimize transport routes taking into account the situation in real time;

- engage in the control and inventory of equipment for preventive maintenance and reduce operating costs;

- $\quad$ ensure safety by monitoring sensitive goods;

- ensure the safety of routes by detecting foreign objects, people in operational areas, unidentified cargoes.

Airobotics developments in this area are interesting [4].

\section{Automated crane equipment}

Moving goods using various modes of transport are expensive and time-consuming. The productivity of crane equipment is one of the most important components of the terminal's performance. Using automated crane equipment is a way to increase the speed and efficiency of container handling, which:

- increases productivity, eliminating the human factor and ensuring no delay in processing;

- $\quad$ reduces operating costs;

- reduces maintenance costs.

\section{Automation of the sea container terminal gates}

The Maritime container terminal is a restricted access zone due to regulated public sector operations (customs, immigration, quarantine, national security), so the gate serves as a key control point for the purpose of identifying and registering each object entering/exiting such zone. Automation of the terminal gate makes the access procedure safe, environmentally friendly and productive:

- $\quad$ reducing the downtime of cars, ships, trains;

- excluding the human factor;

- improve safety.

$\mathrm{ABB}$, Cavotec, Kalmar, and others are engaged in technologies for automation of cranes and terminal gates.

\section{Automated high-rack distribution LCL centers}

Due to the increasing cost of delivering a consignment of goods, the market has seen an increase in the transportation of modular containerized cargo. The solution is the placement and integration of automated distribution LCL centers using a high-rack storage system, managed either by 3PL operators or large shippers, on the territory of an automated sea container terminal. Thus, "the supply chain is reduced both in length and in time", ensuring the most efficient use of the space of the sea container terminal. For example, an empty container can be delivered directly from a high-shelf container storage system to a neighboring distribution center to fill LCL with cargo, thereby reducing transportation costs. 


\section{Unmanned electric saddle truck}

The use of unmanned truck tractors for the internal movement of container equipment between the high-rack system and the LCL distribution center will ensure safety and also increase the operational efficiency of the sea container terminal, including:

- $\quad$ significantly reduce accident rate;

- increase energy efficiency and reduce $\mathrm{CO} 2$ emissions;

- will provide effective interaction with crane equipment and transferrs.

An example of this is Volvo's.

The considered systems should work in a single digital space of a sea container terminal, including using the technology of maintaining distributed accounting and certification registers, Internet things, data mining, including big data processing and more. The proposed project will improve the efficiency of the business processes of the sea container terminal in the context of the development of the container market.

\section{References}

1. E.A. Koroleva, S.S. Sokolov, I.I. Makashina Freight forwarding space as a component of transport and logistic Proceedings of the 2018 IEEE International Conference Quality Management, Transport and Information Security, Information Technologies. (2018)

2. E.A. Koroleva, S.S. Sokolov, I.I. Makashina E.V. Filatova Information technologies as a way of port activity optimization in conditions of digital economy International Scientific Conference "Construction and Architecture: Theory and Practice for the Innovation Development" (CATPID-2019) Environmental Economics and Management E3S Web Conf. 138 (2019).

3. E.A. Koroleva, S.S. Sokolov, I.I. Makashina E.V. Filatova Structural components of space as a component of logistic MATEC Web of Conferences. Siberian Transport Forum, 239, (2018)

4. Official website of the company Airobotics

5. Official website of the company BoxBay

6. Official website of the company Cavotec

7. Official website of the company Wartsila

8. V. A. Galynkin, et al. Catalysis in Industry 3(1), pp 57-61 (2011) doi:10.1134/s2070050411010053Overview of Maritime transport. Report UNCTAD (2019)

9. Volvo Vera: driverless electric truck without cab 